
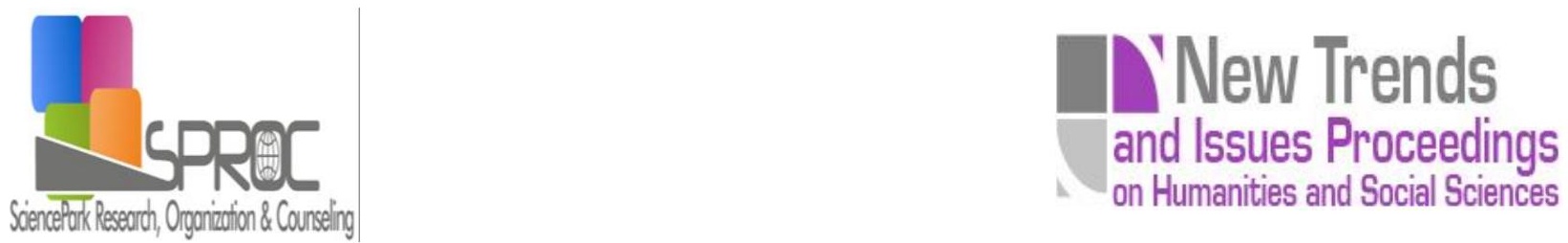

\title{
The management cooperation in Bangbua residential community
}

Rawikarn Amnuay ${ }^{a}$,

Wacharin Intaprom ${ }^{\text {b }}$

Suggested Citation:

Trends and Issues Proceedings on Humanities and Social Sciences.

Abstract

$*$ 
1. Introduction

2. Research objectives

3. Research method 


\section{Research results}


5. Discussion 
6. Recommendations

6.1. Recommendation for policy formulation 


\subsection{Recommendations for further studies}

\section{References}

Collaborative public management: New strategies for local governments

Administration Research Theory

Organizational behavior: A diagnostic approach

\section{Journal of the American Planning Association, 73 Leader to Leader Journal}

Journal of Public

32

Administration Review, 66

Policy Studies Journal,

Public

The Psychiatrist, 
